
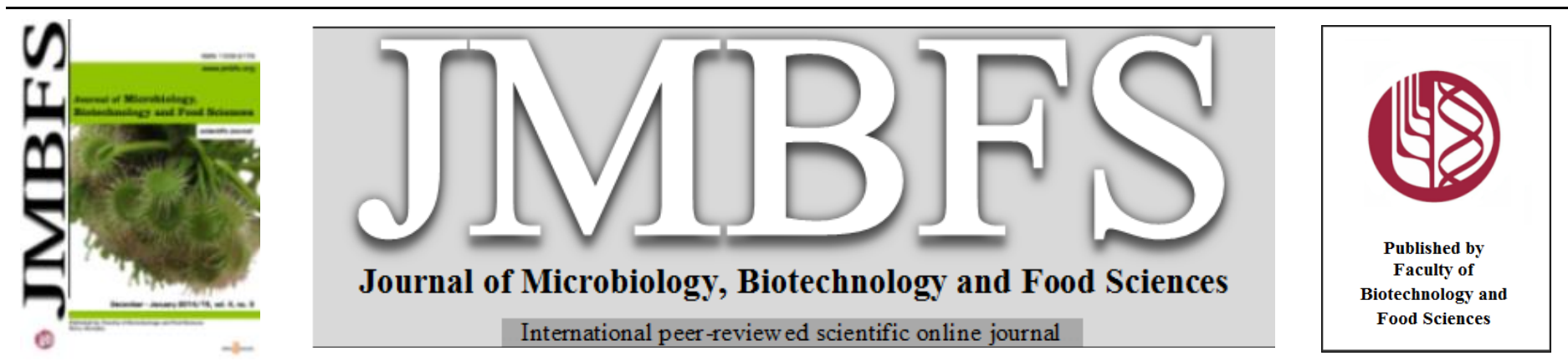

\title{
ANTI-NUTRIENTS, AMINO ACID QUALITY AND PERFORMANCE CHARACTERISTICS OF "NDUDUAGWORAGWO" TRADITIONAL DIET
}

\author{
Majesty K.C. Duru $*^{1}$, Benjamin A. Amadi ${ }^{2}$, Nwadike N. Constance ${ }^{3}$, and Jevas C. Ozougwu ${ }^{4}$
}

Address(es):

${ }^{1}$ Department of Chemical Sciences (Biochemistry Unit), Rhema University, PMB 7021, Aba, Abia State, Nigeria.

${ }^{2}$ Department of Biochemistry, University of Port Harcourt, PMB 5323, Chobba, Rivers State, Nigeria.

${ }^{3}$ Department of Medical Laboratory Science, Imo State University, PMB 2000, Owerri, Imo State, Nigeria.

${ }^{4}$ Department of Biological Sciences (Physiology and Biomedical Research Unit), Rhema University, PMB 7021, Aba, Abia State, Nigeria.

*Corresponding author: kelechukwuduru@gmail.com

doi: 10.15414/jmbfs.2014-15.4.3.252-256

ARTICLE INFO

Received 3. 8. 2014

Revised 21. 10. 2014

Accepted 29. 10. 2014

Published 1. 1. 2015

Regular article

open $\mathcal{O}_{\text {ACCESS }}$

\begin{abstract}
A "nduduagworagwo" is a traditional food of Akokwa people in Imo State, South eastern, Nigeria. Based on the recent linkage of natural foods to health, the anti-nutrients, amino acid quality and performance characteristics of "nduduagworagwo" traditional food was studied. Low levels of cyanogenic glycoside $(0.09 \pm 0.03 \mathrm{mg} / 100 \mathrm{~g})$, phytate $(0.04 \pm 0.00 \mathrm{mg} / 100 \mathrm{~g})$, and oxalate $(0.29 \pm 0.05 \mathrm{mg} / 100 \mathrm{~g})$ anti-nutrients were observed in the studied food. Anti-nutrient/nutrient interactions; oxalate/calcium (0.73), phytate/calcium (0.01), and phytate/iron (0.02) in "nduduagworagwo" were lower than their critical values. Essential and non-essential amino acids were also obtained in the food. The chemical scores for observed amino acids compared favourably with those of reference food materials and some other existing traditional foods. The performance characteristics in this study indicated that "nduduagworagwo" could be an intermediate protein food that can enhance the body with good digestibility $(96.00 \pm 2.87 \%)$ and biological $(58.06 \pm 1.04 \%)$ values. The present study has revealed the anti-nutrients, amino acid quality, and performance characteristic of "nduduagworagwo" traditional food.
\end{abstract}

Keywords: Amino acids, anti-nutrients, "nduduagworagwo", performance characteristics, amino acids, chemical scores

\section{INTRODUCTION}

Food is any edible substance that provides the necessary nutrients required for the proper functioning of the body (Uwakwe and Ayalogu, 1998). In the past, the nutritional status of a group, locality, community or society was in relation to the types of food they eat (Amadi et al., 2011; Kyle and Cole, 2001), although this is not obtainable again since the emergence of fast foods. Okaka and Okaka (2005) noted that food is a mixture of chemicals. The authors went further to state that these chemicals join together to give colour, shape, taste, and flavour to foods. Some of these chemicals are also important due to their roles in energy supply, repair of worn-out body tissues, synthesis of new tissues, and maintenance of several other body functions, etc (Olusanya, 2008; Okaka and Okaka, 2005; Onwuka, 2005). Food chemicals that play such roles are classified as food nutrients. Food nutrients include proteins and the subunit amino acids, carbohydrates, lipids (fats and oils), vitamins, minerals etc. (Amadi et al., 2011; Olusanya, 2008; Okaka and Okaka, 2005; Onwuka, 2005). Aside food nutrients, there are other food chemicals that are not nutrients but play protective roles in the body. These food chemicals aid food nutrients to boost immunity although their ability to do this depends on their levels in the system. Such food chemicals are known as phytochemicals (Njoku and Akumufula, 2007; Stray, 1998). Phytochemicals could become toxic in the body or act as anti-nutrients in food at increased levels. The protective and bioactive activities of these chemicals have been confirmed by different authors (Okigbo et al., 2008; Okwu and Josiah, 2006; Okwu, 2004; Okwu and Okwu, 2004). Most foods both the synthetic and natural foods have nutrients but those that bear phytochemicals are mostly natural foods. The chemical constituents of most natural foods have been determined but information on local foods in Nigeria is still very limited. "nduduagworagwo", a traditional diet made from boiled "ndudu" seeds (Vigna unguiculata subsp. Sesquipedialis), palm oil, "ugba" (fermented sliced P.macrophylla seed), potash, salt, ground paper, "uziza" seed (Piper guineense), "utazi" (Gongronema latifolium) and crayfish., is one of the local foods whose chemical constituents is not well understood. It is a common food among Akokwa people in Ideato North L.G.A of Imo State, Nigeria. It is being said that a visit to Akokwa is incomplete if the visitor did not eat prepared "nduduagworagwo". The people of Akokwa are proud of this food because it is their existing traditional food and showcases their culture.
Due to recent linkage of foods eaten in their natural forms with better health, there is need to investigate the anti-nutrients, amino acid quality, and growth performance characteristics of "nduduagworagwo". This may engineer a renewed interest on local foods especially in this era of increasing cost of convention foods and shortage of resources.

\section{MATERIALS AND METHODS}

\section{Sample collection}

A "ndudu" (vegetable cowpea seed; botanically it is Vigna unguiculata subsp. sesquipedalis),palm oil, "ugba" (fermented sliced P.macrophylla seed), and potash, used in this study were purchased from Akokwa central market. "utazi" (Gongronema latifolium), "uziza" seed (Piper guineense) were collected from Imo State University school farm while the crayfish and salt used in the "nduduagworagwo" preparation were purchased from Owerri main market in Imo State, Nigeria.

\section{A “nduduagworagwo" preparation}

A "nduduagworagwo" was prepared following the traditional method. The "ndudu" seed purchased was sorted for the good ones, which were washed thoroughly with plenty of water. The washed "ndudu" was soaked in water for eight hours to shorten the cooking time. The soaked "ndudu" was then placed in a pot, 4litres of water was added; followed by boiling for about 3hours before it was confirmed fit for consumption. The excess water was drained from the pot and $10 \mathrm{~g}$ of ground pepper, $2 \mathrm{~g}$ of ground potash, $200 \mathrm{ml}$ of red palm oil, $18 \mathrm{~g}$ of ground crayfish, $8 \mathrm{~g}$ of "uziza" seed, and three wraps of "ugba" were added. While mixing the whole components, the filtered water earlier used in cooking the "ndudu" was gradually added at intervals. $75 \mathrm{~g}$ of salt was added to taste. Finally, the boiled "ndudu" was garnished with some sliced "utazi leaves to form "nduduagworagwo", ready to be served. 
Tiny stones and debris remove from Ikg weight of "ndudu"(Vigna ungulculata subsp. Sesqulpedalis).

The damaged ones got further discarded and the good ones selected.

Selected "ndudu" (Vigna ungulculata subsp. Sequlpedalis) washed and soaked for eight hours to shorten the cooking time.

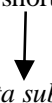

Soaked "ndudu" (Vigna unguiculata subs. Sesquipedalis) + 4 litres of water + heat for 3 hours.

The cooked "ndudu" water was filtered in container and kept

Ten grams of ground pepper, $2 \mathrm{~g}$ of ground potash, $200 \mathrm{ml}$ of red palm oil, $18 \mathrm{~g}$ of ground crayfish, 8g of "uziza" seed (Piper guineense), and three wraps of "ugba" (fermented sliced P.macrophylla seed) were added and mixed together with the cooked "ndudu"

Some filtered water used in cooking "ndudu" kept in the container was added at interval

Seventy- five grams of salt was added to taste + sliced "utazi" (Gongronema latifolium) leaves

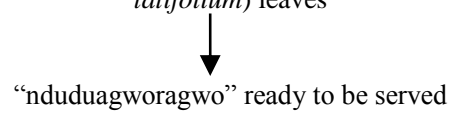

Figure 1 Flow-chart showing "nduduagworagwo" preparation

\section{Sample preparation for analysis}

The prepared "nduduagworagwo" was oven dried at $70^{\circ} \mathrm{C}$ for 48 hours. The dried sample was ground into flour using hand mill device. The ground sample was stored in air tight container till needed for analyses.

\section{Amino acid determination}

The methods of Akubugwo et al., (2006) and Ojiako and Akubugwo (1997) were used for amino acid screening while the method of Speckman et al., (1958) was used for quantitative amino acid analysis of the studied diet. Chemical scores of the individual amino acids were obtained as the ratio of the individual essential amino acids found in "nduduagworagwo"to that of the same amino acid in a reference protein (whole egg of hen)

\section{Anti-nutrient analysis}

Anti-nutrients such as saponins, alkaloids, tannins, flavoniods, cyanogenic glycosides and oxlates were screened with the methods of Harborne (1973) using different extract. Qantitative determination of anti-nutrients considered in the studied food sample were carried using the methods of AOAC (1990).

\section{Anti-nutrient/nutrient ratio}

For anti-nutrient/ nutrient ratio, minerals such as calcium, magnesium, zinc, and iron were determined using atomic absorption spectrophotometer (Buck Scientific, East Norwalk, CT, USA). Anti-nutrient/ nutrient ratio was calculated using the methods of Hassan et al., (2011).

\section{Basal diet}

The protein free or basal diet $\left(\mathrm{D}_{2}\right)$ was formulated by adding $120 \mathrm{~g}$ sucrose, $150 \mathrm{~g}$ cellulose powder, $80 \mathrm{~g}$ red palm oil and $10 \mathrm{~g}$ of vitamin and mineral mixture to $640 \mathrm{~g}$ of corn flour in a bowl and mixed homogenously to give one kilogram of the basal diet.

\section{Reference diet}

The commercial infant food, Nutrend ${ }^{\mathrm{TM}}$ (from Nestle Foods Nigeria PLC) served as the reference diet $\left(\mathrm{D}_{1}\right)$.

\section{Rat feeding study}

Onyeike et al., (1995) method was adopted for rat feeding study. Eighteen disease free stocks of weanling albino rats of the Wistar strain were used in the feeding, which lasted for twenty eight days. The rats were weighed and allowed to acclimatize to their new environment with a commercial rat feed for four days and reweighed. Their initial weights were however taken after acclimatization. The rats were then allocated on the basis of weight and litter origin to three diet groups $\left(D_{1}, D_{2}\right.$, and $\left.D_{3}\right)$ of six rats each in such a way that the group mean weight did not differ by more than $\pm 2.00 \mathrm{~g} /$ mean rat weight. Each of the rats was housed in a single cage with facilities for food, water, faecal and urine collection. Each diet group was given one of the three diets; the compositions of the diets are presented in Table 1

Table 1 Composition of formulated diets $(\mathrm{g} / \mathrm{kg})$ assigned to the different diet group of rats

\begin{tabular}{|c|c|c|c|}
\hline \multirow[t]{2}{*}{ Components } & \multicolumn{3}{|c|}{ Diets } \\
\hline & $\mathrm{D}_{1}$ & $\mathrm{D}_{2}$ & $\mathrm{D}_{3}$ \\
\hline Nutrend ${ }^{\mathrm{TM}}$ & 1000 & - & - \\
\hline Corn Flour & & 640 & \\
\hline Sucrose & $=$ & 120 & $=$ \\
\hline $\begin{array}{l}\text { Vitamin and mineral } \\
\text { mixture }\end{array}$ & & 10 & $=$ \\
\hline RPO & $=$ & 80 & - \\
\hline Cellulose powder & - & 150 & - \\
\hline "Nduduagworagwo" & - & - & 1000 \\
\hline Total (kg) & 1.0 & 1.0 & 1.0 \\
\hline
\end{tabular}

Key= $\mathrm{D}_{1}$ :Nutrend; $\mathrm{D}_{2}$ :Basal diet; $\mathrm{D}_{3}$ :“Nduduagworagwo"; RPO: Red palm oil

$\mathrm{D}_{1}$ received the reference diet consisting of $1000 \mathrm{~g}$ Nutrend ${ }^{\mathrm{TM}}, \mathrm{D}_{2}$ received the basal diet; and $\mathrm{D}_{3}$ received the test diet "nduduagworagwo". Feed and water were administered to the rats ad libitum for a period of twenty-eight days. The rats were weighed weekly. The daily feed intake was recorded, while the faeces were collected daily and dried for analysis. At the end of the feed and water administration period ( 28 days), the rats were finally weighed and then sacrificed with the help of chloroform in a closed container (authanization). Their carcasses were weighed and appropriately labeled. Incisions were made into thoracic and body cavities of the rats to excise their liver, kidneys, heart, spleen, lungs and pancreas. Their weights were also taken. The organs were returned into the individual carcasses and each carcass was dried in an oven at $80^{\circ} \mathrm{C}$ for $72 \mathrm{~h}$, weighed, ground and stored in a desiccator for further nitrogen determination. The feed, faecal and carcass nitrogen contents were analyzed according to standard methods (AOAC, 2006). The methods described by Onyeike and Morris (1996) were used for food conversion ratio (FCR), protein efficiency ratio (PER), net protein utilization (NPU), true digestibility (TD) and biological value $(\mathrm{BV})$.

\section{Statistical analysis}

Data were expressed as means and standard deviations of triplicate determinations. The date were subjected to analysis of variance (ANOVA). Least Significant Difference(LSD) tests was used to establish significance. The significant level of $\mathrm{p}<0.05$ was considered significantly different.

\section{RESULTS AND DISCUSSION}

Anti-nutrients of "nduduagworagwo" (Table 2) showed that tannins content was the highest in the food $(54.16 \mathrm{mg} / 100 \mathrm{~g})$, followed by saponins $(24.7 \mathrm{mg} / 100 \mathrm{~g})$ Tannins and saponins due to their respective astringent and better taste may affect palatability and digestibility of food (Okwu and Ndu, 2006; Akwaowo et al. 2000; Osagie, 1998). The value of saponins (Table 3) in the present study was the highest when compared to those of "onunu" and "mgbam" traditional foods, while its tannins content (Table 3$)$ was significantly $(\mathrm{p}<0.05)$ higher than that of "onunu" and significantly $(\mathrm{p}<0.05)$ lower than that of "mgbam" (Amadi et al. 2011). The importance of alkaloids and flavonoids in foods and in the biological system cannot be overemphasized (Olowokudoejo et al., 2008; Ninmh, 1996) Alkaloid content of the studied food was the highest (Table 3) against that of "onunu" and "mgbam" foods while its flavonoid content was the lowest when compared to those of "mgbam" and "onunu" (Amadi et al., 2011). A daily intake of $450 \mathrm{mg}$ of oxalic acid has been reported to interfere with metabolism (Akawaowo et al., 2000). High oxalate levels in food may reduce the bioavailability of such metals as calcium, magnesium, and zinc thereby interfering with their utilization (Omorayi et al., 2007; Oluyemi et al., 2006; Pingle and Ramastrin, 1978). Phytic acid intake of 4-9 $\mathrm{mg} / 100 \mathrm{~g}$ reduces iron absorption by 4-5 folds in humans (Hurrel et al., 1992). The phytate content observed in the studied food was the lowest (Table 3) when compared to those of "onunu" and "mgbam" while its oxalate content was comparable to that of "mgbam" (Table 3). The cyanogenic glycoside when in small amount in food 
poses no threat to the body. The observed cyanogenic glycoside content of "nduduagworagwo" in the present study poses no threat to the human system due to its low level and was comparable to those of "mgbam" and "onunu" traditional foods (Table 3).

Hassan et al., (2011), Akwaowo et al., (2000) and Hurrel et al., (1992) noted the ability of some anti-nutrients to interact with some nutrients. These interactions may hinder the bioavailability of these nutrients. The values of mineral elements such as calcium $(0.40 \pm 0.08 \mathrm{mg} / 100 \mathrm{~g})$, magnesium $(0.24 \pm 0.03 \mathrm{mg} / 100 \mathrm{~g})$, zinc $(0.10 \pm 0.01 \mathrm{mg} / 100 \mathrm{~g})$, and iron $(0.16 \pm 0.07 \mathrm{mg} / 100 \mathrm{~g})$ detected in the "nduduagworagwo" were used to determine the anti nutrient/nutrient ratio of the studied recipe (Table 4). The values obtained for oxalate/calcium, oxalate/ [calcium + magnesium], phytate/zinc, phytate/calcium, phytate/iron and [calcium][phytate]/[zinc] interactions were lower than their critical values (Table 4 ). The implication herein could be that both oxalate and phytate constituents of the studied food will not have effect on the bioavailability of its calcium, zinc, magnesium, and iron mineral elements.

Okaka and Okaka (2005) noted that some amino acids must be obtained from diets. According to Olusanya (2008), amino acids that must be obtained from diets are addressed as essential amino acids. Essential amino acids observed in the present study (Table 5) include valine, isoleucine, methionine, leucine, phenylalanine, threonine, lysine, histidine, and arginine. Non-essential amino acids found in the studied food (Table 7) include asparagine, serine, proline, glycine, cystine, and tryrosine.

Table 2 Anti-nutrient constituents of "nduduagworagwo"

\begin{tabular}{lc}
\hline Anti-nutrients (mg/100g) & "nduduagworagwo" \\
\hline Saponins & $24.70 \pm 0.12$ \\
\hline Alkaloids & $7.65 \pm 0.38$ \\
\hline Tannins & $54.16 \pm 1.20$ \\
\hline Flavonoids & $12.70 \pm 0.71$ \\
\hline Cyanogenic glycosides & $0.09 \pm 0.03$ \\
\hline Phytate & $0.04 \pm 0.00$ \\
\hline Oxalate & $0.29 \pm 0.05$
\end{tabular}

Results are means and standard deviations of triplicate determinations.

Table 3 Anti-nutrient constituents of "nduduagworagwo" compared to those of "onunu" and "mgbam"

\begin{tabular}{lccc}
\hline $\begin{array}{l}\text { Anti- } \\
\text { nutrients } \\
(\mathbf{m g} / \mathbf{1 0 0 g})\end{array}$ & "nduduagworagwo" & "onunu" & "mgbam" \\
\hline Saponins & $24.70 \pm 0.12^{\mathrm{c}}$ & $12.70 \pm 0.20^{\mathrm{b}}$ & $10.65 \pm 0.20^{\mathrm{a}}$ \\
\hline Alkaloids & $7.65 \pm 0.38^{\mathrm{c}}$ & $5.06 \pm 0.18^{\mathrm{b}}$ & $1.82 \pm 0.10^{\mathrm{a}}$ \\
\hline Tannins & $54.16 \pm 1.20^{\mathrm{b}}$ & $43.20 \pm 1.10^{\mathrm{a}}$ & $93.60 \pm 2.00^{\mathrm{c}}$ \\
\hline Flavonoids & $12.16 \pm 0.71^{\mathrm{a}}$ & $23.76 \pm 0.18^{\mathrm{b}}$ & $77.88 \pm 2.00^{\mathrm{c}}$ \\
\hline $\begin{array}{l}\text { Cyanogenic } \\
\text { glycosides }\end{array}$ & $0.09 \pm 0.03^{\mathrm{a}}$ & $0.08 \pm 0.40^{\mathrm{a}}$ & $0.12 \pm 0.16^{\mathrm{a}}$ \\
\hline Phytate & $0.04 \pm 0.00^{\mathrm{a}}$ & $5.06 \pm 1.05^{\mathrm{c}}$ & $1.82 \pm 0.10^{\mathrm{b}}$ \\
\hline Oxalate & $0.29 \pm 0.05^{\mathrm{b}}$ & $0.14 \pm 0.02^{\mathrm{a}}$ & $0.26 \pm 0.07^{\mathrm{a}}$ \\
\hline
\end{tabular}

Results are means and standard deviations of triplicate determinations. Values bearing different superscript in row vary significantly $(\mathrm{p}<0.05)$. Data for antinutrient constituents of "onunu" and "mgbam" sourced from Amadi $\boldsymbol{e t}$ al. (2011).

Table 4 Anti-nutrient/ nutrient ratio of "nduduagworagwo" compared to their critical values

\begin{tabular}{lcc} 
Anti-nutrient/nutrient ratio & "nduduagworagwo" & Critical values \\
\hline Oxalate/calcium & 0.73 & 2.50 \\
\hline Oxalate/[calcium+magnesium] & 0.45 & 2.50 \\
\hline Phytate/zinc & 0.05 & 10.00 \\
\hline Phytate/calcium & 0.01 & 0.20 \\
\hline Phytate/iron & 0.03 & 0.40 \\
\hline [calcium][phytate]/zinc & 0.02 & 0.50
\end{tabular}

Critical value for each ratio sourced from Hassan et al., (2011).

Table 5 Essential amino acid composition of "nduduagworagwo" (mg/g Nitrogen)

\begin{tabular}{lc}
\hline Essential amino acid & "nduduagworagwo" \\
\hline Valine & $228 \pm 0.23$ \\
\hline Isolucine & $290 \pm 0.10$ \\
\hline Methionine & $70 \pm 0.24$ \\
\hline Leucine & $410 \pm 0.31$ \\
\hline Phenylalanine & $321 \pm 0.49$ \\
\hline Threonine & $180 \pm 1.20$ \\
\hline Lysine & $309 \pm 0.70$ \\
\hline Histidine & $186 \pm 0.31$ \\
\hline Arginine & $410 \pm 0.80$ \\
\hline Results are means and standard deviation of triplicate determination.
\end{tabular}

Table 6 Essential amino acid composition of "nduduagworagwo" compared to those of reference foods (mg/g Nitrogen)

\begin{tabular}{lcccc}
\hline $\begin{array}{l}\text { Essential } \\
\text { amino acid }\end{array}$ & "nduduagworagwo" & $\begin{array}{c}\text { Whole } \\
\text { hen`s egg }\end{array}$ & Casein & $\begin{array}{c}\text { Cow`s } \\
\text { milk }\end{array}$ \\
\hline Valine & 228 & 428 & 438 & 362 \\
\hline Isolucine & 290 & 393 & 345 & 295 \\
\hline Methionine & 70 & 210 & 178 & 157 \\
\hline Leucine & 410 & 551 & 607 & 596 \\
\hline Phenylalanine & 321 & 358 & 334 & 336 \\
\hline Threonine & 180 & 320 & 297 & 278 \\
\hline Lysine & 309 & 436 & 518 & 487 \\
\hline Histidine & 186 & 152 & 186 & 167 \\
\hline Arginine & 410 & 381 & 239 & 205 \\
\hline Datar
\end{tabular}

Data for essential amino acids in reference foods sourced from FAO (1972).

Table 7 Non-essential amino acid composition of "nduduagworagwo" (mg/g Nitrogen)

\begin{tabular}{lc}
\hline Non-essential amino acid & "nduduagworagwo" \\
\hline Asparagine & $428 \pm 1.90$ \\
\hline Serine & $183 \pm 0.56$ \\
\hline Glutamin acid & $\mathrm{ND}$ \\
\hline Proline & $193 \pm 0.37$ \\
\hline Glycine & $2861 \pm 0.22$ \\
\hline Alanine & $320 \pm 1.83$ \\
\hline Cystine & $120 \pm 0.39$ \\
\hline Tyrosine & $273 \pm 0.10$ \\
\hline
\end{tabular}

Results are means and standard deviation of triplicate determinations.

ND: Not detected

Table 8 Non-essential amino acid composition of "nduduagworagwo" compared to those of reference foods ( $\mathrm{mg} / \mathrm{g}$ Nitrogen)

\begin{tabular}{lcccc}
\hline $\begin{array}{l}\text { Non-essential } \\
\text { amino acid }\end{array}$ & "nduduagworagwo" & $\begin{array}{c}\text { Whole } \\
\text { hen`s egg }\end{array}$ & Casein & $\begin{array}{c}\text { Cow`s } \\
\text { milk }\end{array}$ \\
\hline Asparagine & 428 & 601 & 455 & 481 \\
\hline Serine & 183 & 478 & 385 & 362 \\
\hline Glutamin acid & ND & 796 & 1406 & 1390 \\
\hline Proline & 193 & 260 & 738 & 571 \\
\hline Glycine & 286 & 207 & 126 & 123 \\
\hline Alanine & 320 & 370 & 196 & 217 \\
\hline Cystine & 120 & 152 & 23 & 51 \\
\hline Tryrosine & 273 & 260 & 337 & 297 \\
\hline
\end{tabular}

Data for non-essential amino acids in reference foods sourced from FAO (1972). ND: Not Detected.

Table 9 Chemical scores (\%) of "nduduagworagwo" food

\begin{tabular}{lc}
\hline Chemical Score & "nduduagworagwo" \\
\hline Valine & $53.27 \pm 0.13$ \\
\hline Isoleucine & $73.79 \pm 0.29$ \\
\hline Methionine & $33.33 \pm 0.10$ \\
\hline Leucine & $74.41 \pm 0.28$ \\
\hline Phenylalanine & $89.66 \pm 0.31$ \\
\hline Threonine & $56.25 \pm 0.62$ \\
\hline Lysine & $70.87 \pm 0.80$ \\
\hline Histidine & $122.37 \pm 0.21$ \\
\hline Arginine & $107.61 \pm 0.03$
\end{tabular}

Results are means and standard deviation of triplicate determinations.

Table 10 Chemical scores of "nduduagworagwo" compared to those of "onunu" and "mgbam" traditional foods

\begin{tabular}{lccc}
\hline Chemical score & "nduduagworagwo" & "onunu" & "mgbam" \\
\hline Valine & $53.27 \pm 0.13^{\mathrm{b}}$ & $49.00 \pm 4.06^{\mathrm{a}}$ & $71.26 \pm 1.00^{\mathrm{c}}$ \\
\hline Isoleucine & $73.79 \pm 0.29^{\mathrm{b}}$ & $66.15 \pm 0.15^{\mathrm{a}}$ & $82.09 \pm 2.69^{\mathrm{c}}$ \\
\hline Methionine & $33.33 \pm 0.10^{\mathrm{b}}$ & $28.57 \pm 4.04^{\mathrm{a}}$ & $85.71 \pm 2.50^{\mathrm{c}}$ \\
\hline Leucine & $74.41 \pm 0.28^{\mathrm{a}}$ & $99.89 \pm 0.41^{\mathrm{b}}$ & $127.04 \pm 7.01^{\mathrm{c}}$ \\
\hline Phenylalanine & $89.66 \pm 0.31^{\mathrm{b}}$ & $78.21 \pm 0.21^{\mathrm{a}}$ & $100.43 \pm 1.88^{\mathrm{b}}$ \\
\hline Threonine & $56.25 \pm 0.62^{\mathrm{a}}$ & $71.87 \pm 1.87^{\mathrm{b}}$ & $97.18 \pm 1.96^{\mathrm{c}}$ \\
\hline Lysine & $70.87 \pm 0.80^{\mathrm{a}}$ & $69.03 \pm 1.22^{\mathrm{a}}$ & $72.70 \pm 0.40^{\mathrm{a}}$ \\
\hline Histidine & $122.37 \pm 0.21^{\mathrm{a}}$ & $118.42 \pm 2.42^{\mathrm{a}}$ & $173.02 \pm 1.20^{\mathrm{b}}$ \\
\hline Arginine & $107.61 \pm 0.03^{\mathrm{a}}$ & $107.61 \pm 0.61^{\mathrm{a}}$ & $190.20 \pm 12.21^{\mathrm{b}}$ \\
\hline
\end{tabular}

Results are means and standard deviations of triplicate determinations. Values bearing different superscript in row vary significantly $(\mathrm{p}<0.05)$. Chemical scores of "onunu" and "mgbam" sourced from Benjamin et al., (2011). 
Table 11 Performance characteristics of rats fed "nduduagworagwo"

\begin{tabular}{lccc}
\hline $\begin{array}{l}\text { Performance } \\
\text { characteristics }\end{array}$ & “nduduagworagwo" & Basal feed & Nutrend \\
\hline $\begin{array}{l}\text { Body weight } \\
\text { change (g) }\end{array}$ & $60.27 \pm 1.99^{\mathrm{b}}$ & $5.52 \pm 0.17^{\mathrm{a}}$ & $84.14 \pm 0.12^{\mathrm{c}}$ \\
\hline $\begin{array}{l}\text { Total food } \\
\text { intake (g) }\end{array}$ & $258.33 \pm 3.05^{\mathrm{c}}$ & $5.52 \pm 0.20^{\mathrm{a}}$ & $234.63 \pm 1.29^{\mathrm{b}}$ \\
\hline $\begin{array}{l}\text { Carcass } \\
\text { nitrogen (g) }\end{array}$ & $4.01 \pm 0.16^{\mathrm{a}}$ & $231.70 \pm 3.11^{\mathrm{b}}$ & $5.94 \pm 0.74^{\mathrm{a}}$ \\
\hline $\begin{array}{l}\text { Faecal nitrogen } \\
\text { (g) }\end{array}$ & $3.52 \pm 0.31^{\mathrm{a}}$ & $3.18 \pm 1.20^{\mathrm{a}}$ & $3.33 \pm 0.10^{\mathrm{a}}$ \\
\hline $\begin{array}{l}\text { Total nitrogen } \\
\text { intake (g) }\end{array}$ & $4.90 \pm 0.82^{\mathrm{b}}$ & $0.84 \pm 0.13^{\mathrm{a}}$ & $6.98 \pm 0.19^{\mathrm{c}}$ \\
\hline $\begin{array}{l}\text { Total protein } \\
\text { intake (g) }\end{array}$ & $32.06 \pm 1.01^{\mathrm{b}}$ & $1.16 \pm 0.29^{\mathrm{a}}$ & $43.67 \pm 0.73^{\mathrm{c}}$ \\
\hline $\begin{array}{l}\text { Food } \\
\text { conversion ratio }\end{array}$ & $0.19 \pm 0.08^{\mathrm{a}}$ & $7.24 \pm 0.15^{\mathrm{b}}$ & $0.34 \pm 0.01^{\mathrm{a}}$ \\
\hline $\begin{array}{l}\text { Protein } \\
\text { efficiency ratio }\end{array}$ & $1.67 \pm 0.29^{\mathrm{b}}$ & $0.021 \pm 0.01^{\mathrm{a}}$ & $1.93 \pm 0.28^{\mathrm{b}}$ \\
\hline $\begin{array}{l}\text { Net protein } \\
\text { retention }\end{array}$ & $1.33 \pm 0.10^{\mathrm{b}}$ & $0.00^{\mathrm{a}}$ & $1.80 \pm 0.30^{\mathrm{b}}$ \\
\hline $\begin{array}{l}\text { Net protein } \\
\text { utilization }(\%)\end{array}$ & $53.08 \pm 1.31^{\mathrm{b}}$ & $0.00^{\mathrm{a}}$ & $55.00 \pm 1.22^{\mathrm{b}}$ \\
\hline $\begin{array}{l}\text { True } \\
\text { digestibility }(\%)\end{array}$ & $96.95 \pm 2.87^{\mathrm{c}}$ & $0.00^{\mathrm{a}}$ & $64.00 \pm 0.13^{\mathrm{b}}$ \\
\hline $\begin{array}{l}\text { Biological value } \\
\text { (\%) }\end{array}$ & $58.06 \pm 1.04^{\mathrm{b}}$ & $0.00^{\mathrm{a}}$ & $87.10 \pm 0.14^{\mathrm{c}}$ \\
\hline Re a
\end{tabular}

Results are means and standard deviations of triplicate determinations. Values bearing different superscript in row vary significantly $(p<0.05)$.

Table 12 Performance characteristics rats fed "nduduagworagwo" compared to those of "onunu" and "mgbam" traditional foods

\begin{tabular}{lccc}
\hline $\begin{array}{l}\text { Performance } \\
\text { characteristics }\end{array}$ & “nduduagworagwo" & “onunu" & “mgbam" \\
\hline $\begin{array}{l}\text { Body weight } \\
\text { change (g) }\end{array}$ & $60.27 \pm 1.99^{\mathrm{c}}$ & $32.10 \pm 1.14^{\mathrm{a}}$ & $54.31 \pm 4.14^{\mathrm{b}}$ \\
\hline $\begin{array}{l}\text { Total food } \\
\text { intake (g) }\end{array}$ & $258.33 \pm 3.05^{\mathrm{c}}$ & $240.82 \pm 2.14^{\mathrm{b}}$ & $5.12 \pm 0.06^{\mathrm{a}}$ \\
\hline $\begin{array}{l}\text { Carcass nitrogen } \\
\text { g) }\end{array}$ & $4.01 \pm 0.16^{\mathrm{b}}$ & $3.99 \pm 0.03^{\mathrm{b}}$ & $1.14 \pm 0.03^{\mathrm{a}}$ \\
\hline $\begin{array}{l}\text { Faecal Nitrogen } \\
\text { (g) }\end{array}$ & $3.52 \pm 0.31^{\mathrm{b}}$ & $0.94 \pm 0.02^{\mathrm{a}}$ & $5.15 \pm 0.09^{\mathrm{c}}$ \\
\hline $\begin{array}{l}\text { Total nitrogen } \\
\text { intake (g) }\end{array}$ & $4.09 \pm 0.82^{\mathrm{a}}$ & $4.61 \pm 0.10^{\mathrm{ab}}$ & $5.15 \pm 0.09^{\mathrm{b}}$ \\
\hline $\begin{array}{l}\text { Total protein } \\
\text { intake (g) }\end{array}$ & $32.06 \pm 1.01^{\mathrm{a}}$ & $28.87 \pm 0.50^{\mathrm{a}}$ & $32.19 \pm 0.58^{\mathrm{a}}$ \\
\hline $\begin{array}{l}\text { Food conversion } \\
\text { ratio }\end{array}$ & $0.19 \pm 0.08^{\mathrm{a}}$ & $0.13 \pm 0.004^{\mathrm{a}}$ & $0.22 \pm 0.005^{\mathrm{a}}$ \\
\hline $\begin{array}{l}\text { Protein } \\
\text { efficiency ratio }\end{array}$ & $1.67 \pm 0.29^{\mathrm{b}}$ & $1.11 \pm 0.02^{\mathrm{a}}$ & $1.68 \pm 0.03^{\mathrm{b}}$ \\
\hline $\begin{array}{l}\text { Net protein } \\
\text { retention }\end{array}$ & $1.33 \pm 0.10^{\mathrm{b}}$ & $0.91 \pm 0.22^{\mathrm{a}}$ & $1.51 \pm 0.20^{\mathrm{b}}$ \\
\hline $\begin{array}{l}\text { Net protein } \\
\text { utilization }(\%)\end{array}$ & $53.08 \pm 1.31^{\mathrm{b}}$ & $42.50 \pm 0.03^{\mathrm{a}}$ & $60.00 \pm 0.02^{\mathrm{c}}$ \\
\hline $\begin{array}{l}\text { True } \\
\text { digestibility }(\%)\end{array}$ & $96.00 \pm 2.87^{\mathrm{a}}$ & $97.00 \pm 0.05^{\mathrm{a}}$ & $93.00 \pm 0.04^{\mathrm{a}}$ \\
\hline $\begin{array}{l}\text { Biological value } \\
(\%)\end{array}$ & $58.06 \pm 1.04^{\mathrm{b}}$ & $43.77 \pm 5.37^{\mathrm{a}}$ & $63.64 \pm 6.54^{\mathrm{c}}$ \\
\hline
\end{tabular}

Results are means and standard deviations of triplicate determinations. Values bearing different superscript in row vary significantly $(\mathrm{p}<0.05)$. Data for performance characteristic of rats fed "onunu" and "mgbam" diets were sourced from Benjamin et al., (2011)

Comparing these amino acids to those of reference foods (Tables 6 and 8 ) showed that their levels are appreciable in the studied food sample. Sharon and Davis (2008) noted the importance of these amino acids in the human system. Chemical scores of "nduduagworagwo" food (Table 9) revealed the presence of amino acids in the following order; arginine > histidine> phenylanine> isoleucine> lysine>threonine>valine> methionine. Methionine is therefore the limiting amino acid in the present study. The low methionine content observed in the present study is in line with Okaka and Okaka (2005) who noted that legumes are low in sulphur containing amino acids such as methionine and cystine. Histidine is very essential for infants (Olusanya, 2008) hence the observed high value of histidine in the present study may qualify "nduduagworagwo" as a suitable food for growing infants.

Table 10 compared the chemical scores of observed amino acids in "nduduagworagwo" to those of "onunu" and "mgbam" traditional foods. Observed results showed that apart from leucine and threonine, chemical scores of valine, isoleucine, methionine, phenylalanine were significantly $(\mathrm{p}<0.05)$ higher in "nduduagworagwo" against those of "onunu". Lysine, arginine and histidine amino acids in "nduduagworagwo" were comparable to those of "onunu" traditional food. The chemical scores of all the observed amino acids apart from phenylalanine and lysine, were significantly $(\mathrm{p}<0.05)$ higher in "mgbam" traditional food than "nduduagworagwo". The chemical scores of phenylalanine and lysine in "nduduagworagwo" and "mgbam" in this study are comparable. The observed chemical scores of the present study could mean that "nduduagworagwo" is higher than "onunu" and lower than "mgbam" in terms of protein quality.

Olusanya (2008) noted that the measurement of protein quality of a foodstuff is determined by its ability to promote growth which in turn is dependent on the essential amino acids. Aside the simple procedure of using chemical scores to determine protein quality of a food material, a more biological approach of using the food material as a feeding stuff to laboratory animals (growing rats for example) also exist (Olusanya, 2008). Table 11 revealed the performance characteristics of rats fed "nduduagworagwo" to those given nutrend and basal diets. The total food intake was highest in rats placed on "nduduagworagwo" than those on nutrend and basal diets. This could be due to palatability of the food over nutrend and basal diet. Benjamin et al., (2012) and Anyika et al., (2009) noted that food intake can be influenced by palatability, source of nitrogen and essential amino acid profile. Rats placed on the studied food gained relative higher weight over rats on basal diet but lower than those on nutrend. This could be attributed to the constituents of the diets. Total nitrogen intake (TNI), and total protein intake (TPI) were highest in rats placed on nutrend followed by rats placed on "nduduagworagwo" diet. Carcass nitrogen $(\mathrm{CN})$, and food conversion ratio (FCR) were highest in rats placed on basal diet. Protein efficiency ratio (PER) is based on the fact that weight gain in a growing animal is proportional to the gain in body protein (Mortimore, 1982). According to Benjamin et al., (2012); and Friedman (1996) protein efficiency ratio (PER) value below 1.5 indicates a protein of poor quality; between 1.5 and 2.0 an intermediate quality and above 2.0 good quality proteins. It could therefore be inferred that "nduduagworagwo" food and nutrend used in the present study with protein efficiency ratio (PER) values of 1.67 and 1.93 are intermediate quality proteins and this could be behind the body weight gained by the rats placed on these two recipes than rats on basal diet. The net protein retention (NPR) and net protein utilization (NPU) were insignificantly $(\mathrm{p}<0.05)$ affected in rats placed on "nduduagworagwo" when compared to those on nutrend. True digestibility (TD) was the highest in rats placed on "nduduagworagwo" when compared to true digestibility (TD) in rats placed on basal diet and nutrend. The biological values $(\mathrm{BV})$ was significantly higher $(\mathrm{p}<0.05)$ in rats placed on "nduduagworagwo" against those on basal diets but lower when compared to those on nutrend. This could be indication that "nduduagworagwo" can enhance growth, relatively increase weight, and will be well digested when consumed in the system. On comparing performance characteristics of rats placed on "nduduagworagwo" to those of "onunu" and "mgbam" traditional foods (Table 12), it was observed that rats placed on "nduduagworagwo" had highest body weight change (BWC) and total food intake (TFI) to those of "onunu" and "mgbam" diets. This could be related to digestibility and palatability of the studied food."nduduagworagwo" also compared favourably in other performance characteristics such as carcass nitrogen $(\mathrm{CN})$, total nitrogen intake (TNI), total protein intake (TPI), net protein utilization (NPU), true digestibility (TD) and biological value (BV) to those of "onunu" and "mgbam" traditional foods.

\section{CONCLUSION}

This study has shown the anti-nutrients, amino acid quality and performance characteristics of "nduduagworagwo" traditional food. From the observations of the present study, "nduduagworagwo" had low anti-nutrients and anti-nutrient/ nutrient ratio interactions, appreciable amino acid quality and produced better growth performance characteristics in rats than basal diet and some traditional foods. "nduduagworagwo" could therefore be a good source of protein and some mineral elements in the body.

\section{REFERENCES}

AKUBUGWO, E. I., ARUKWE, U.I., CHINYERE.G. C. 2006. Identification of constituents amino acids of polypeptides and proteins by chemical tests In; A practical work-book on base chemistry and qualitative analysis of biomolecules. Research and Academic Publishers, Owerri, Nigeria.pp.193-204.

AKWAOWO, E.U., NDON, B. A., ETUK, E. U. 2000. Minerals and antinutrients in fluted pumpkin (Telfaria occidentalis Hook F). Food Chem. 70, 235 240. http://dx.doi.org/10.1016/s0308-8146(99)00207-1

AMADI, B. A., AYAlOGU, E. O., ONYEIKE.E. N. 2011. Nutrient and antinutient composition of "onunu" and "mgbam", traditional foods of Ikwerre ethnic nationality in South-South, Nigeria. JETEAS 2(3), 551- 555

ANYIKA, J.U., OBIZOBA, I. C., OJIMELUKWE. P. 2009. Effect of food intake on weight gain, liver weight and composition in rats fed dehulled African yam bean and bambara groundnut supplemented with sorghum or crayfish. Pak J. Nutr. 8(4), 500 - 504. http://dx.doi.org/10.3923/pjin.2009.500.504 
AOAC.1990.Official methods of analysis (15 th edn.,).Washington DC, USA. Association of official analytical chemists inch 400-2200 Wilson Boalevard, Arlinton Virginia USA, 1990; 2 910-92.

AOAC (Association of Official Analytical Chemists) 2006. Official method of analysis of the AOAC (W. Horwitz Edition) $18^{\text {th }}$ edition, Washington DC.

BENJAMIN, A. A., AYALOGU, O. E.,ONYEIKE. E.N. 2011. Performance characteristics and organ weight of rats fed "onunu" and "mgbam" traditional diets of the Ikwerre people of Niger Delta, Nigeria". Continental J. Food Science and Techn. 6(1), 12-19. http://dx.doi.org/10.5707/cjfst.2012.6.1.13.20

FAO.1972.Amino acid content of food and biological data on proteins, Report of Food and Agricultural Organisation/United Nations Joint Committee, Rome,pp.116.

FRIEDMAN, M. 1996. Nutritional value of proteins from different foods sources. A review. J. Agric. Food Chem 44:6-12 http://dx.doi.org/10.1021/jf9400167

HARBORNE, J. B.1973. Phytochemical methods. A guide to modern technique of plant analysis. $2^{\text {nd }}$ edn., Chapman and Hall, New York. HASSAN, L.G., UMAR, K.J., DANGOGGO, S.M., MAIGANDI, A. S. 2011. Anti-nutrient composition and bioavailability predication as exemplified by calcium, iron and zinc in Melocia corchonifolia leaves. Pak.J. Nutr. 10, 23-24. http://dx.doi.org/10.3923/pjn.2011.23.28

HURREL, R.F., JULIET, M. A., REDDY, M. B., LYNCH, S. R., DASSENKO, S., COOK. J. D. 1992. Soy protein, phytate and iron absorption in humans. Am J. Clin.Nutr. 56, 573-578.

KYLE, R., COLE, E. 2001. Classification of food In; food and nutrition", $2^{\text {nd }}$ edn. Bruce and World Inc. New York. pp. 21-29.

NINMH, A. C.1996. The encyclopedia of medicinal plants. Dorling Kindersley. London

NJOKU, P. C., AKUMUFULA. M. I. 2007. Phytochemical and nutrients evaluation of Spondias mombi leaves. Pak. J.Nutr. 6(6), 613-615. http://dx.doi.org/10.3923/pjn.2007.613.615

MORTIMORE, G.E. 1982. Mechanism of Cellular Protein Metabolism. Nutrition

Reviws. 41, 1-8.

OJIAKO, O. A., AKUBUGWO. E. I. 1997. Chemistry and qualitative tests of protein In; an introductory approach to practical biochemistry. CRC publications, Owerri, Nigeria. 33-40 p.

OKAKA, J.C., OKAKA. A. N. C. 2005. Foods: composition, spoilage, shelf-life extension. Ocjanco academic publishers, Enugu. pp.1-93.

OKIGBO, R. N., EME, U.E., UGBOGU, S. 2008. Biodiversity and conservation of medicinal and aromatic plants in Africa. Biotechnol Mol. Bio. Rev. 3(6), 127 134

OKWU, D. E. 2004. Phytochemicals and vitamin content of indigenous spices of Southeaster, Nigeria. J. Sustain Agric Environ. 6(1), 30-37. OKWU, D.E., JOSIAH.C. 2006. Evaluation of chemical composition of two Nigerian medicina plants. Afr. J. Biotechnol. 5 (4), 357-361. OKWU, D. E., NDU. C. U. 2006. Evaluation of the phytonutrients, mineral and vitamin contents of some varieties of yam (Dioscorea sp.). International Journal of Mol. Med. and Advances Sciences 2(2), 199-203

OKWU, D. E., OKWU, M. E. 2004. Chemical composition of spondias mombim Linn plant parts. J.Sustain Agric. Environ. 6(2), 140-147. OLOWOKUDOEJO, J. D., KADIRI, A. B., TRAVIH, V. B. 2008. An ethnobatanical survey of herbal markets and medicinal plants in Lagos State, Nigeria. Ethnobotan. Leaflets 12 (8), 51-65.

OLUSANYA, J. O. 2008. Essentials of food and nutrition, $1^{\text {st }}$ edtion. Apex book limited Lagos, 36-148 pp. ISSBN 978-978-48045-54 OLUYEMI, E. A., AKILULA, A.A., ADENUYA, A.A., ADEBAYO, A. A. 2006. Mineral contents of some commonly consumed Nigerian foods. Sci Focus.11,153-157.

OMORAYI, F. O., DILWORTH, L. 2007. Anti-nutritional factors, zinc, iron, and calcium in some cariggean tuber crops and effect of boiling or roasting. Nutr Food Sci. 37, 8-15. http://dx.doi.org/10.1108/00346650710726904

ONWUKA, G.I. 2005.Food analysis and instrumentation (theory and practical). $1^{s t}$ edn. Napthali prints, Surulere, Lagos- Nigeria. 140-160. ONYEIKE, E. N., AYALOGU, E. O., UZOGARA. S. G. 1995. Influence of heat processing of african yam bean seed (Sphenostylis stenocarpa) flour on the growth and organ weight of rats. Plant Foods for Human Nutri. 48, 85-93. http://dx.doi.org/10.1007/bf01088303

Onyeike, E.N., Morris. P. I. 1996. Evaluation of the nutritional quality of a weaning food from african yam bean-rice-prawn mixture. Delta Agric. 3,134147.

OSAGIE, A.U.1998. Anti-nutritional factors In: nutritional quality of plant foods. $1^{\text {st }}$ edn., post-harvest research unit, University of Benin, Benin City, 221 $244 \mathrm{pp}$

PINGLE U., RAMASTRIN. B. V. 1978. Effect of water soluble oxalate in Amaranthus sp. on the absorption of milk calcium. Br.J. Nutr. 40, 591-594. http://dx.doi.org/10.1079/bjn19780163

SHARON, W., DAVID.M. 2008. Biochemistry, Demystified. McGraw Hill Companies United States, 131-135pp.

SPACKMAN, D. H., STEIN, W.H., MOORE. S. 1958. Automatic recording apparatus for use in the chromatography of amino acids. Anal Chem.1190-1191. http://dx.doi.org/10.1021/ac60139a006
STRAY, F.1998. The natural guide to medicinal herbs and plants. Tiger books international, London. pp. 12-16.

UWAKWE, A. A., AYAlOGU, E. O. 1998. Nutrition In: biochemistry, a tropical approach volume 1. Fius Publishers, Port Harcourt, Nigeria, 1-33 pp. ISBN 978-33412-7-8-A 